\author{
ks. Krzysztof Gryz ${ }^{1}$ \\ Uniwersytet Papieski Jana Pawła II w Krakowie
}

\title{
Poszukiwanie życia w kosmosie a teologia
}

\section{Streszczenie}

W XX wieku podjęto wiele działań badawczych, których celem było znalezienie dowodów wskazujących na istnienie życia w kosmosie. Działania te mogą być także przedmiotem refleksji teologii. Pole tej refleksji wypełniają dwa nurty myślenia. Pierwsze jest czysto hipotetyczne, jako że dowodów na istnienie życia dotąd nie odkryto. Druga przestrzeń refleksji jest bardziej realna i koncentruje się np. na sensie poszukiwania innych cywilizacji: czy ludzkie istnienie jest czymś wyjątkowym we wszechświecie, czy tęsknota na inną, wyższą formą cywilizacji nie jest wyrazem odwiecznej tęsknoty za doskonałością i pragnieniem życia nieśmiertelnego?

Słowa kluczowe: Kosmos, życie, teologia, grzech pierworodny, odkupienie

\section{Summary}

\section{Searching for Life in Space and Theology}

In the twentieth century, a number of research activities were undertaken, the purpose of which was to find evidence, indicating the existence of life in space. These activities can also be the subject of theological reflection. The field of this reflection is filled with two trends of thought. The first one is purely hypothetical, since the evidence for the existence of life has not been discovered yet. The second area of reflection is more real and focuses, for example, on the sense of searching for other civilizations, whether human existence is something special in the universe, or is it a longing for a different, higher form of civilization is it not an expression of the eternal longing for perfection and for immortal life?

Keywords: Cosmos, live, theology, original sin, redemption

1 Ks. Krzysztof Gryz (ORCID: 0000-0001-7311-9780) - dr hab., studia specjalistyczne z teologii moralnej w Universidad de Navarra (Pampeluna, Hiszpania); kierownik Katedry Teologii Moralnej Ogólnej Uniwersytetu Papieskiego Jana Pawła II w Krakowie. Zastępca redaktora naczelnego „Analecta Cracoviensia”. Członek Stowarzyszenia Teologów Moralistów. W 2010 roku habilitował się na podstawie pracy pt. Antropologia przebóstwienia. Obraz człowieka w teologii prawosławnej. 
Już starożytni Grecy podejrzewali, że jakieś formy życia mogą istnieć w kosmosie. W IV wieku przed Chr. epikurejczyk Metrodor z Lampsakos (330-227) był przekonany o tym, że twierdzenie, iż planeta Ziemia to jedyny zaludniony świat w nieskończonej przestrzeni jest równie absurdalne jak to, że na całym polu prosa wyrośnie tylko jedno ziarenko. W miarę jak rozwija się wiedza na temat kosmosu, jego rozmiarów i złożonej budowy oraz w miarę jak dokonywane są nowe odkrycia układów słonecznych podobnych do naszego i planet ${ }^{2}$ pojawia się pytanie, czy istnieje możliwość istnienia życia we wszechświecie, w szczególności zaś życia, które charakteryzuje się inteligencją i świadomością.

\section{Badania naukowe}

Wszechświat jest olbrzymią przestrzenią składającą się z około 350 miliardów dużych galaktyk i 3,5 biliona galaktyk karłowatych, a w każdej znajduje się od $10^{7}$ do $10^{12}$ gwiazd orbitujących wokół wspólnego środka masy. Szacuje się, że w naszej galaktyce może znajdować się około 400 miliardów gwiazd. Wydaje się jednak, wobec wciąż powiększających się możliwości poznania kosmosu, że wielkości te mogą być daleko niedoszacowane. Kosmos jest z pewnością o wiele większy, niż to już wiemy, a nawet niż nam się wydaje.

Uwzględniając wiedzę (tę przyrodniczą) na temat procesu powstawania życia na Ziemi, wielu naukowców jest przekonanych, że jeśli na jakiejś planecie we wszechświecie istnieją podobne warunki do tych, jakie istniały i istnieją na Ziemi, co jest bardzo prawdopodobne, to również wysoce prawdopodobne jest i to, że wykształciły się tam jakieś formy ży$\mathrm{cia}^{3}$. Rozumowanie to odwołuje się z jednej strony do zasady kopernikań-

2 Wszystkich planet pozaziemskich znamy już 3946. Pierwszą planetę pozasłoneczną odkryto w 1988 roku, zaś pierwszą planetę mogącą przypominać Ziemię - Gliese 581c odkryto w 2007 roku. W 2017 roku NASA poinformowała o odkryciu układu siedmiu planet podobnych do Ziemi i Wenus znajdujących się w odległości „zaledwie” 40 lat świetlnych od Ziemi.

3 Nie wszyscy naukowcy podzielają takie przekonanie. Prof. Marek Abramowicz pisze: „z punktu widzenia nauki powstanie inteligentnego życia na Ziemi jest zdarzeniem wstrząsająco nietypowym, splotem szczęśliwych przypadków o tak niesłychanie małym 
skiej, mówiącej, że Ziemia nie jest szczególnie wyróżnionym miejscem we wszechświecie, a jedynie typową planetą, podlegającą tym samym prawom, efektom i prawdopodobieństwu co inne, z drugiej zaś do teorii Darwina o pochodzeniu gatunków. Dlaczego zatem w tak olbrzymiej przestrzeni miałaby istnieć tylko jedna inteligentna cywilizacja? Takie pytanie stawia sobie wielu naukowców. Niektórzy z nich próbują nawet oszacować liczbę pozaziemskich inteligentnych cywilizacji. Najbardziej znanym jest Frank Drake, autor tzw. równania Drake’a, według którego ilość ta może wynosić od tysiąca do setek milionów ${ }^{4}$. Biorąc pod uwagę, że współczynniki jego równania są bardzo szacunkowe, inni naukowy zawężają tę liczbę do miliona. Co pewien czas pojawiają się odkrycia wskazujące na taką możliwość, np. istnienie wody na Europie (księżycu Jowisza) czy też meteorycie ALH84001, który miał być nosicielem śladów życia z Marsa, a spadł na Antarktydę 13 tysięcy lat temu. Meteoryt zawiera ślady związków organicznych węgla, przypominających te, które powstają podczas rozkładu planktonu lub towarzyszą rozwojowi pewnych bakterii.

Systematyczną próbą odnalezienia cywilizacji pozaziemskich był uruchomiony w latach sześćdziesiątych minionego wieku w Stanach Zjednoczonych program SETI (Search for Extra-Terrestial Intelligence). Jego zadaniem było prowadzenie stałego nasłuchu fal radiowych docierających z kosmosu w celu wyodrębnienia sygnałów emitowanych przez istoty rozumne. Założono bowiem, że inteligentni kosmici korzystają, tak jak Ziemianie, z urządzeń emitujących fale radiowe. W latach 1977-1990 odebrano z kilku gwiazdozbiorów sygnały, które uznano za sztuczne, czyli niebędące wynikiem naturalnych zjawisk fizycznych występujących

prawdopodobieństwie, że fakt naszego istnienia jest po prostu zdumiewającym cudem" M. Abramowicz, Pan Bóg jest wyrafinowany, ale nie perfidny, „Przewodnik Katolicki” 18 (2016), s. 24.

4 Równanie Drake’a brzmi: $\mathrm{N}=\mathrm{R}^{*} \cdot \mathrm{f}_{\mathrm{p}} \cdot \mathrm{n}_{\mathrm{e}} \cdot \mathrm{f}_{1} \cdot \mathrm{f}_{\mathrm{i}} \mathrm{f}_{\mathrm{c}} \cdot \mathrm{L}$, gdzie poszczególne składowe oznaczają: $\mathrm{N}$ - liczba cywilizacji pozaziemskich, z którymi ludzkość może się komunikować; $\mathrm{R}^{*}$ - szybkość powstawania gwiazd w naszej galaktyce; $\mathrm{f}_{\mathrm{p}}$ - odsetek gwiazd, które posiadają planety; $\mathrm{n}_{\mathrm{e}}$ - średnia liczba planet, na których może powstać życie; $\mathrm{f}_{1}$ - odsetek tych planet, na których życie powstanie; $\mathrm{f}_{\mathrm{i}}$ - odsetek tych planet, na których rozwinie się życie inteligentne; $\mathrm{f}_{\mathrm{c}-}$ odsetek tych cywilizacji, które będą chciały podjąć komunikację z ludzkością; $\mathrm{L}$ - średni czas istnienia takich cywilizacji. 
w przyrodzie. Jednak z powodu braku wystarczających efektów tych działań zaprzestano nasłuchu. Kontynuacją SETI jest sponsorowany przez prywatne firmy program „Phoenix”, który stawia sobie za cel systematyczne i dokładne poszukiwanie sygnałów radiowych z otoczenia około tysiąca gwiazd podobnych do Słońca. Od 1998 roku do tych badań wykorzystywany jest największy na świecie radioteleskop „The Arecibo" (jego antena ma 305 m średnicy). W 2009 roku NASA umieściła na okołosłonecznej orbicie satelitę Kepler, którego zadaniem jest wykrywanie planet poza Układem Słonecznym w oparciu o zmianę blasku gwiazdy (na skutek przechodzącej przez jego tarczę planety). Spośród 190 tysięcy obserwowanych gwiazd taką zmianę wykryto u 11 tysięcy, co wskazuje, że mogą mieć one układy słoneczne.

Oprócz działań pasywnych podejmowano także aktywne próby nawiązania ewentualnego kontaktu z obcymi cywilizacjami. Przykładem takiej próby było umieszczenie na sondzie kosmicznej Voyager 1, wystrzelonej w kosmos przez NASA 5 września 1977 roku, 12-calowej płyty gramofonowej wykonanej z pozłacanej miedzi (nazwanej Golden Record), która zawierała nagrane pozdrowienia w 55 językach, muzykę, dźwięki i obrazy przedstawiające życie i kulturę na Ziemi, graficzny schemat Układu Słonecznego, symbol atomu wodoru oraz graficzne wizerunki mężczyzny i kobiety. Umieszczono także zakodowaną instrukcję, jak należy odczytać dane z płyty.

Wszystkie te działania nie przyniosły jednak bezspornego i bezpośredniego dowodu na istnienie życia (nawet w najprostszej formie) w Układzie Słonecznym. Jeszcze trudniej o takie potwierdzenie w odniesieniu do odległych układów gwiezdnych, z którymi komunikacja jest bardzo utrudniona, a tym bardziej do innych galaktyk. Wyraźna sprzeczność między teoretycznie wysoko oszacowanym prawdopodobieństwem istnienia życia w kosmosie a brakiem jakichkolwiek obserwacyjnych śladów jego istnienia rodzi paradoks, który określany jest mianem „paradoksu Fermiego", od nazwiska włoskiego naukowca Enrico Fermiego (19011954), któremu przypisuje się słynne pytanie: Where Are They? (Gdzie oni są?), wypowiedziane w 1950 roku. Fermi zauważa, że wielkość i wiek wszechświata sugerują, iż powinno istnieć wiele zaawansowanych technicznie pozaziemskich cywilizacji. Tymczasem takiemu rozumowaniu 
przeczy brak obserwacyjnych dowodów ich istnienia. Zatem, albo początkowe założenia są nieprawidłowe i zaawansowane technicznie życie jest znacznie rzadsze niż się sądzi, albo nasze metody obserwacji są niekompletne i ludzkość jeszcze ich nie wykryła, albo nasze metody są błędne i poszukujemy niewłaściwych śladów.

Wskazuje się zasadniczo na trzy typy rozwiązań owego paradoksu: 1) doskonalenie empirycznych badań kosmosu prowadzonych w coraz to nowszych wymiarach poznawczych; 2) inteligentne cywilizacje istnieją, ale kontakt z nimi jest niemożliwy; aby istniała możliwość komunikacji z innymi cywilizacjami, te musiałyby osiągnąć ogromny poziom technologiczny, wymagający bardzo długiego okresu do rozwoju, który mógłby być dłuższy niż sam czas istnienia owych cywilizacji. Niektórzy wskazują, że obcy komunikują się z nami w sposób, który przewyższa nasze technologiczne możliwości, albo za pomocą metod niewykorzystywanych jeszcze przez ludzkość. Sugeruje się, że niektóre zjawiska parapsychologiczne, mistyczne lub opisane w tekstach religijnych mogą być formą takiej właśnie komunikacji. Jeszcze inni sądzą, że obcy nie chcą się z nami kontaktować, bo ludzkość nie stanowi dla nich odpowiedniego partnera; 3) odrzucenie idei istnienia istot rozumnych w kosmosie; życie na Ziemi jest tak unikalnym zjawiskiem, że prawdopodobieństwo powtórzenia się takiej zbieżności praktycznie nie istnieje (zasada antropiczna, która mówi, że cały wszechświat ze wszystkimi jego uwarunkowaniami ukierunkowany był na powstanie życia na Ziemi ${ }^{5}$ ).

Wszystko to przemawia za tym, że fakt istnienia cywilizacji pozaziemskiej długo jeszcze, jeśli nie na zawsze, pozostanie jedynie teorią. Niektórzy jednak zauważają, że podobnie jak nie ma stuprocentowego dowodu na istnienie życia w kosmosie, tak też nie ma stuprocentowej pewności, że ono nie istnieje, a zatem nie można zaprzeczać czemuś, co nie zostało jeszcze odkryte, a jest bardzo prawdopodobne. Na bazie tego przekonania powstała oddzielna dziedzina naukowa - astrobiologia (egzobiologia, kosmobiologia), która zajmuje się badaniem możliwości istnienia i rozwoju życia na innych ciałach niebieskich.

5 Por. S. Hawking, Krótka historia czasu, Warszawa 20152, s. 198-201; J. Morales, El misterio de la Creación, Pamplona 1994, s. 183-184. 


\section{Hipotetyczne pytania dla teologii}

Niezależnie jednak od rezultatów prowadzonych badań i dokonanych odkryć z punktu widzenia teologicznego możemy zwrócić uwagę na trzy kwestie, które rodziłyby pytania dla teologii ${ }^{6}$. Nie dotyczą one samej możliwości istnienia życia w kosmosie, ponieważ ta kwestia przekracza kompetencje teologii. Nie jest ona nauką przyrodniczą ani też futurystyczną. Jest nauką, która odwołuje się do danych Objawienia i w oparciu o nie prowadzi swoje refleksje. Ponieważ jednak do tej pory nie odkryto inteligentnego życia w kosmosie, są to pytania jedynie hipotetyczne.

Po pierwsze, pojawia się argument, że stworzenie całego olbrzymiego kosmosu tylko po to, aby na jednej planecie, wcale nie największej i nieznajdującej się w jego centrum - co wykazał Kopernik - byłoby niczym nieuzasadnioną i nadmierną rozrzutnością Boga. Jest bardziej prawdopodobne, że skoro Bóg powołał do istnienia tak olbrzymi wszechświat, to uczynił to z myślą o wielu żywych istnieniach, nie tylko o człowieku? Dla samego człowieka Bóg nie potrzebowałby aż tak bardzo się trudzić.

Odpowiadając na takie wątpliwości, trzeba najpierw stwierdzić, że wszechświat okazuje się konstrukcją wysoko skomplikowaną, w którym wszystkie elementy, nawet te najmniejsze, oddziałują na siebie, tworząc w efekcie warunki do powstania środowiska przyjaznego życiu w takiej postaci, o jakiej mówimy, to znaczy którego szczytowym momentem jest człowiek. Gdyby choć jedna z cech owego układu, takich jak grawitacja, prędkość rozszerzania się przestrzeni czy wielkość sił wiążących protony i neutrony w jądrach atomów, miała odrobinę inną wartość niż ma, nasz kosmos już dawno rozwiałby się w pustce lub zapadł do swego środka. Nie powstałyby w nim gwiazdy, a w konsekwencji

6 Marek Abramowicz, uwzględniając możliwość - nawet czysto hipotetyczną - istnienia obcych, formułuje pytania teologiczne: „[...] czy mieliby duszę? Czy ciążyłby na nich grzech pierworodny, wymagający odkupienia? Czy mogliby być zbawieni i czy zmartwychwstałyby ich ciała, zupełnie niepodobne do naszych? Czy byłyby wśród nich inne narody wybrane, z którymi Bóg zawarłby inne Przymierze? Czy ich aniołowie to byliby ci sami aniołowie, co nasi [...]?" - M. Abramowicz, Pan Bóg jest wyrafinowany, ale nie perfidny, dz. cyt., s. 27.

7 Ks. Michał Heller mówi o racji teologicznej, jaką jest stwórcza płodność Boga. Por. M. Heller, Czy kosmita może być zbawiony, „Tygodnik Powszechny” (8.06.2008), s. 28-29. 
także organizmy żyjące i wreszcie ludzie. Okazuje się, że wielkość i czas istnienia kosmosu musiała być ogromna, aby mogły powstać warunki dla życia ${ }^{8}$. Gdyby np. wszechświat był o połowę młodszy, to czas około $6 \mathrm{mld}$ lat byłby za mały i zbyt „słaby”, aby mogły powstać te pierwiastki, które tworzą nasze ciała. Zabrakłoby materiału na zbudowanie Ziemi, roślin, zwierząt, a w końcu i człowieka. A zatem domniemana „rozrzutność” Stwórcy okazuje się pozorna. Do tych faktów odwołuje się tzw. hipoteza jedynej Ziemi (Rare Earth Hypothesis), mówiąca, że powstanie złożonego życia na Ziemi wymagało nieprawdopodobnej kombinacji wielu czynników astrofizycznych i geologicznych, trudnych do powtórzenia, w związku z czym jest wysoce prawdopodobne, że życie istnieje tylko na Ziemi.

Poza tym, nawet jeśli we wszechświecie zostały na jakiejś planecie spełnione wszystkie warunki możliwe do powstania życia i rzeczywiście istnieje tam jakaś jego forma, nie oznacza to automatycznie, że rozwijało się ono (czy też będzie się rozwijać) według znanego nam schematu ewolucji w postać życia inteligentnego, jakim jest człowiek. Dusza ludzka jako z natury swojej duchowa, nie podlega prawom ewolucji biologicznej, jej istnienie nie jest wynikiem biologicznych procesów udoskonalających materię, ale jest owocem bezpośredniej ingerencji Boga. Jej pojawienie się oznacza zaangażowanie Boga, a co za tym idzie, akt miłości z Jego strony. Istoty obdarzone duchową naturą (niezależnie od tego gdzie się one znajdują) byłyby tak samo kochane przez Boga uniwersalną i powszechną miłością jak ludzkość i w konsekwencji dar zbawienia byłby przeznaczony także dla nich.

Nie jest to jednak decydujący argument. Nawet gdyby przyjąć, że pojawienie się życia mogło odbyć się w innych warunkach fizycznych, to owa

8 Por. S. Hawking odpowiadając na pytanie, dlaczego był potrzeby tak długi okres do powstania wszechświata, stwierdza, że był potrzebny, aby mogły powstać w drodze ewolucji inteligentne istoty. Co więcej, wszechświat musiał się rozwijać w takim właśnie tempie: „Gdyby początkowe tempo ekspansji było mniejsze o jedną tysięczną jednej milionowej jednej milionowej procenta, to wszechświat już dawno zapadłby się ponownie", Krótka historia czasu, dz. cyt., s. 194. I dalej: „Jeśli standardowy model wielkiego wybuchu jest poprawny aż do początkowej osobliwości, to stan początkowy wszechświata musiał być wybrany z nadzwyczajną precyzją. Byłoby bardzo trudno wyjaśnić, czemu wszechświat musiał rozpocząć swą ewolucję od takiego właśnie stanu, chyba że był to akt Boga, chcącego stworzyć istoty takie jak my" - S. Hawking, Krótka historia czasu, dz. cyt., s. 202. 
hojność Boga nie dziwi w perspektywie dzieła odkupienia człowieka. Bóg kocha człowieka taką samą absolutną i bezgraniczną miłością nawet gdyby żyła na Ziemi tylko jedna osoba. Z tej miłości i dla tej osoby, dla każdego człowieka, nie tylko dla ludzkości jako wielkiej zbiorowości osób, Bóg dokonuje dzieła zbawienia, które ma nieskończony wymiar. Jeśli Bóg poświęcił dla człowieka swojego Jednorodzonego Syna, który jest wartością absolutnie nieporównywalną ze wszystkimi doskonałościami kosmosu, to nie może zaskakiwać fakt, że Bóg stworzył ów kosmos właśnie jedynie z myślą o człowieku. Na tę właśnie prawdę wskazuje Jan Paweł II, kiedy pisze: „Jakąż wartość musi mieć w oczach Stwórcy człowiek, skoro zasłużył na takiego i tak potężnego Odkupiciela".

Po wtóre, jeśli istniejące istoty są obdarzone rozumną i wolną naturą, to znaczy, że posiadają zdolność poznawania prawdy i dokonywania wolnych wyborów, a to z kolei oznacza, że są obdarzone duszą i jako takie są istotami osobowymi, umiłowanymi przez Boga i zaproszonymi do osobowej relacji z Nim, właściwej ich naturze. Obejmuje je także powszechna wola zbawcza Boga i są odkupione męką i zmartwychwstaniem Chrystusa, niezależnie od tego, że do tej pory nie są tego świadome. Odkupienie wyjednane przez Chrystusa dotyczy bowiem wszystkich istot stworzonych, nie tylko tych, które żyły w Jego czasach, ale także i tych, które rodzą się i będą rodzić się w przyszłości. Dotyczy to także tych istot, których istnienia do tej pory nie uświadamiamy sobie, podobnie jak to miało miejsce z ludami i plemionami poznanymi w XVI wieku w czasie wielkich odkryć geograficznych, przede wszystkim Ameryki. W tej sprawie prowadzono ożywione dysputy w środowisku prawników i teologów Uniwersytetu w Salamance w kontekście jurysdykcji nad podbitymi ludami, w których to dyskusjach przewijało się pytanie o to, czy można ich traktować jak ludzi i czy ich również obejmuje dzieło zbawcze Chrystusa. Mimo iż nie posiadano wówczas wiedzy dotyczącej rozwoju gatunku ludzkiego, co mogło sugerować, że ludy te ukształtowały się niezależnie od innych, wypracowano jednoznaczną odpowiedź na to, jak powinno się ich traktować. Dokonali tego zwłaszcza dwaj teologowie: Francisco de Vitoria (1483-1546) i Domingo de Soto (1494-1560). Pierwszy z nich

9 Jan Paweł II, Encyklika Redemptor hominis (4.03.1979), 10, Kraków 1982. 
$\mathrm{w}$ traktacie De Indis ${ }^{10}$ udowadniał, że jako istoty rozumne podlegają takim samym prawom naturalnym i boskim, jak wszyscy ludzie. Z tego powodu traktuje się go jako ojca prawa narodów, ius gentium, które obejmuje wszystkich ze względu na powszechne braterstwo. W tym samym duchu wypowiadał się także Domingo de Soto w traktacie De dominio ${ }^{11}$.

Oddzielny problem dotyczy grzechu pierworodnego. Czy istoty pozaziemskie dziedziczą winę Adama, a jeśli tak, to na jakiej zasadzie? Ks. Michał Heller skłaniałby się do przypuszczenia, że wśród takich istot nie nastąpił grzech pierworodny, „gdyż mają lepiej rozwinięty umysł i wyraźniej widzą różnicę między dobrem a złem. Żyją zatem w przyjaźni ze Stwórcą i nie wymagają odkupienia"12. Trzeba jednak podkreślić, że odkupienie nie sprowadza się tylko do zgładzenia grzechu i winy. Jest to jedynie jego aspekt „negatywny”. W rzeczywistości odkupienie jest zaproszeniem człowieka do pełnego zjednoczenia z Bogiem, które nie jest możliwe bez Jego interwencji. Odkupienie jest łaską, która nas nie tylko uwalnia i oczyszcza, ale przemienia i uzdalnia do upodobnienia się do Boga. Ten aspekt odkupienia pominął ks. Heller. Poza tym, jeśli grzech pierworodny zburzył harmonię w kosmosie, to skutki tego faktu dotykają wszystkie istoty w nim żyjące, niezależnie od tego, czy są świadome tego faktu, czy też nie.

Z zagadnieniem grzechu pierworodnego wiąże się problem jego przekazywania. Czy powszechna solidarność w grzechu, o której zaświadcza Pismo Święte, wymaga rzeczywiście, aby u początku życia świata istniała jedna tylko para osób? W drugiej połowie XX wieku refleksja teologiczna próbowała rozważać, czy monogenizm jest koniecznym wymogiem uzasadniającym powszechne doświadczenie grzechu i udział w nim wszystkich potomków Adama ${ }^{13}$. Sobór Trydencki używa pojęcia per propagatione, natomiast Pius XII, odrzucając teorię poligenizmu, i stojąc na stanowisku monogenizmu jako odpowiadającego prawdzie o dziedziczeniu grzechu

10 Por. Francisco de Vitoria, O Indianach, Warszawa 1954.

11 Domingo de Soto, De dominio, Salamanca 1560. Wydanie krytyczne tego dzieła to: Domingo de Soto, Relección De Dominio, ed. de Jaime Bufrau Prats, Granada 1964.

12 M. Heller, Czy kosmita może być zbawiony..., dz. cyt., s. 28.

13 Por. B. Hałaczek, Ewolucja poglądów teologicznych na ewolucję, „Śląskie Studia Historyczno-Teologiczne" 31 (1998), s. 17-25. 
pierworodnego, używa pojęcia per generatione $e^{14}$. Z kolei Paweł VI w tzw. Credo Ludu Bożego (30 czerwca 1968) powraca do pojęcia per propagatione ${ }^{15}$. Bazując na tej precyzacji terminologicznej twierdzi się, że pojęcie per propagatione (polskim odpowiednikiem tego pojęcia mogą być następujące terminy: rozpowszechnienie, rozkrzewienie, rozszerzenie albo przedłużenie) jest pojęciem szerszym niż per generatione i zdolnym objąć także inne rodzaje wyjaśnień przekazywania grzechu pierworodnego, niż to sugerujące zrodzenie, a więc w konsekwencji pochodzenie całej ludzkości od jednej tylko pary ${ }^{16}$. W latach sześćdziesiątych-siedemdziesiątych ubiegłego wieku niektórzy teologowie próbowali interpretować grzech pierworodny w taki sposób, aby nie był on koniecznie związany z monogenizmem i tym samym nie sprzeciwiałby się dogmatycznemu nauczaniu Kościoła na temat grzechu pierworodnego ${ }^{17}$. Teorie te nie zostały

14 „Jeśli zaś chodzi o inną hipotezę, mianowicie poligenizm, to synowie Kościoła wcale już nie mają podobnej wolności. Nie wolno bowiem wiernym przyjmować opinii, której zwolennicy twierdzą, że po Adamie istnieli na ziemi ludzie nie pochodzący od niego, jako prarodzica, drogą naturalnego rozmnażania się, lub że Adam oznacza pewną liczbę prarodziców. Okaże się bowiem całkiem niemożliwe, jakby się dało pogodzić taką teorię z nauką źródeł prawdy Objawionej i dokumentów Kościoła Nauczającego o grzechu pierworodnym, który pochodzi z grzechu rzeczywiście popełnionego przez jednego Adama i przeszczepiany rodzeniem na wszystkich jest zarazem wrodzonym grzechem własnym każdego człowieka" (Pius XII, Humani generis, III, 1).

15 „Tenemus igitur, Concilium Tridentinum secuti, peccatum originale, una cum natura humana transundi propagatione, non imitatione, idque inesse unicuique proprium" (Utrzymujemy za Soborem Trydenckim, że grzech pierworodny bywa przekazywany wraz z naturą ludzką przez rozszerzenie a nie naśladowanie i że jest własnym grzechem każdego), AAS 8 (1968), s. 439.

16 Wydaje się jednak, że pojęcie zrodzenia jest logiczną konsekwencją pojęcia propagatione. Chodzi bowiem o to, że tak jak ludzka natura jest przekazywana poprzez zrodzenie, tak teżjest dziedziczony grzech pierworodny, który jest skażeniem owej natury. Ze względu na to, że w przeszłości wysnuwano czasem błędne wnioski z użycia terminu generatione, sugerujące, że sam akt zrodzenia jest „przyczyną” grzechu, bo w jego efekcie człowiek rodzi się ze skazą grzechową, współczesne Magisterium powróciło do klasycznego pojęcia propagatione. Nie ma to jednak związku z teorią poligenizmu.

17 W latach 60. XX wieku Karl Rahner występował z tezą, że „w obecnym stanie nauk przyrodniczych i teologii nie można udowodnić z pewnością, że poligenizmu nie da się pogodzić z ortodoksyjną nauką o grzechu pierworodnym”, K. Rahner, Grzech pierworodny a ewolucja, „Concilium” 1-10 (1966-1967), s. 290. Podobne badania prowadzili także jezuiccy teologowie: Z. Alszeghy i M. Flick, R. Schwager. Por. T. Stwora, Próby interpretacji nauki o grzechu pierworodnym w świetle teorii ewolucji w teologii katolickiej, „Studia Ełckie” 14 (2012), 
jednak powszechnie przyjęte, tak że kwestia grzechu pierworodnego u ewentualnych obcych wydaje się sprawą otwartą.

Jedność rodzaju ludzkiego w relacji do Adama mogłaby być innej natury niż wynika to z biologicznego rodzenia. Sobór Watykański II mówi o jedności całego rodzaju ludzkiego, której ostatecznym uzasadnieniem jest Bóg. To On jest początkiem i celem każdego człowieka i z tego powodu cała ludzkość tworzy jedność. Jest to zatem nie tyle jedność biologiczna, będąca wynikiem fizycznej ciągłości rodzaju ludzkiego, której początkiem jest jedna para, ale jedność teologiczno-moralna ${ }^{18}$. Podobną naukę odnajdujemy w Katechizmie Kościoła katolickiego, który mówi o jedności początku, natury, celu i misji w świecie, jedności zamieszkania (jedna ziemia) i jedności celu nadprzyrodzonego, a także jedności odkupienia ${ }^{19}$. Niemniej jednak mowa jest tu o jedności rodzaju ludzkiego, a nie jedności istot rozumnych. Pozostaje pytanie, czy owa ,jedność” obejmowałaby $\mathrm{w}$ jakimś sensie wszystkie istoty rozumne istniejące we wszechświecie i na czym miałaby się fundować?

Z drugiej strony, jak stwierdza Sobór Watykański II, ci, którzy poznali Chrystusa i Jego zbawcze orędzie, są moralnie zobowiązanie do tego, by je przyjąć i przez chrzest stać się uczestnikami Jego odkupienia. Natomiast ci, którzy

s. 453-468; T.D. Łukaszuk, Zwiazek dogmatu o grzechu pierworodnym z monogenizmem w katolickiej teologii ostatniej doby, Warszawa 1976.

18 „Wszystkie bowiem ludy stanowią jedną wspólnotę, mają jeden początek, ponieważ Bóg sprawił, że rodzaj ludzki zamieszkuje całą powierzchnię ziemi, mają też jeden ostateczny cel - Boga. Jego opatrzność, świadectwo dobroci i zbawcze plany rozciągają się na wszystkich ludzi, póki wybrani nie zjednoczą się w Świętym Mieście, które oświetlone będzie blaskiem chwały Boga i gdzie narody chodzić będą w Jego świetle" (Sobór Watykański II, Deklaracja o stosunku Kościoła do religii niechrześcijańskich Nostra aetate, 1). Por. Sobór Watykański II, Konstytucja dogmatyczna o Kościele Lumen gentium, 13.

19 „Dzięki wspólnemu początkowi rodzaj ludzki stanowi jedność. Bóg bowiem «z jednego człowieka wywiódł cały rodzaj ludzki» (Dz 17, 26): Wspaniała wizja, która pozwala nam kontemplować rodzaj ludzki w jedności jego początku w Bogu... w jedności jego natury, u wszystkich złożonej tak samo z materialnego ciała i duchowej duszy; w jedności jego bezpośredniego celu i jego misji w świecie; w jedności miejsca jego zamieszkania - ziemi oraz dóbr, z których wszyscy ludzie na podstawie prawa naturalnego mogą korzystać, by podtrzymywać i rozwijać swoje życie; w jedności celu nadprzyrodzonego, którym jest sam Bóg, do którego wszyscy mają dążyć; w jedności środków potrzebnych do osiągnięcia tego celu... w jedności odkupienia, którego dla wszystkich dokonał Chrystus" (KKK 360). 
[...] bez własnej winy nie znając Ewangelii Chrystusa i Jego Kościoła, szczerym sercem szukają jednak Boga, a Jego wolę poznaną przez nakaz sumienia starają się pod wpływem łaski wypełniać w swoim postępowaniu, mogą osiągnąć wieczne zbawienie. Nie odmawia też Opatrzność Boża pomocy koniecznej do zbawienia tym, którzy bez własnej winy w ogóle nie doszli jeszcze do wyraźnego poznania Boga, a usiłują, nie bez łaski Bożej, prowadzić uczciwe życie ${ }^{20}$.

Istnieje zatem możliwość, że w ową wspólnotę jednoczącą się z Bogiem włączeni są wszyscy, którzy obdarzeni są osobowym istnieniem.

\section{Realne pytania teologii}

Na przestrzeni wieków teologia nauczyła się wstrzemięźliwości w szukaniu odpowiedzi na hipotetyczne pytania, które jej zadawano, bądź które sama sobie stawiała. Prowadziły one bardzo często na manowce ludzką myśl i wypaczały prawdy wiary. Dlatego istnieje słuszny dystans teologii wobec tych zagadnień. Przykładem może być stanowisko Kościoła wobec propozycji arcybiskupa Waszyngtonu Patricka J. O’Boyle'a, który reagując na wielkie zainteresowanie możliwością istnienia istot pozaziemskich, jakie rozwinęło się w USA w latach pięćdziesiątych pod wpływem doniesień o obecności w naszej przestrzeni tzw. niezidentyfikowanych obiektów latających (UFO), przesłał do komisji przygotowawczej propozycję, aby mający się odbyć Sobór Watykański II wypowiedział się na temat możliwości inteligentnego życia na innych planetach w świetle doktryny o stworzeniu i odkupieniu. Propozycja ta słusznie jednak nie spotkała się z zainteresowaniem komisji i nie weszła pod soborowe obrady.

Paradoksalnie, bardziej niż same wyniki poszukiwań inteligentnej formy życia w kosmosie interesujący dla antropologii teologicznej jest sam fakt ich podjęcia.

Po pierwsze, w wysiłkach naukowców poszukujących obcych cywilizacji w kosmosie, daje się zauważyć, obok naturalnej naukowej ciekawości, która inspiruje poszukiwanie prawdy, jakąś głęboką wewnętrzną potrzebę odkrycia innych inteligentnych istot, co pozwoliłoby pozbyć się poczucia osamotnienia człowieka w kosmosie. Sądzi się, że ich wiedza,

\footnotetext{
20 Sobór Watykański II, Konstytucja dogmatyczna o Kościele Lumen gentium, 16.
} 
która z jakichś powodów z pewnością miałaby przewyższać naszą, może być pomocna w udzieleniu odpowiedzi na odwieczne pytanie człowieka o jego pochodzenie i przeznaczenie: skąd jesteśmy i jaka jest przyszłość ludzkości? Zakłada się, że odkrycie takich cywilizacji wniesie coś istotnego dla naszej cywilizacji, nie tylko na poziomie technologicznym, ale także nada jakiś nowy sens istnieniu samego człowieka. Jest to mesjańska nadzieja zsekularyzowanego człowieka, poddanego urokowi techniki. Jeśli człowiek redukuje samego siebie i swój los tylko do wymiaru doczesnego, może odczuwać pewną samotność w kosmosie. Jeśli jednak człowiek wie, że jego los jest związany z Bogiem, który go kocha i oczekuje go w swoim królestwie, to wówczas znika poczucie samotności i niedowartościowania. Wręcz przeciwnie, godność człowieka dopełnia się w tym, że Bóg stworzył go dla niego samego - lub jak wyraził to Sobór Watykański II: „człowiek jest na ziemi jedynym stworzeniem, którego Bóg chciał ze względu na niego samego" 21 - i człowiek odnajduje ostateczną rację i cel swojego istnienia w zjednoczeniu z Bogiem.

Po drugie, znalezienie inteligentnej formy życia poza Ziemią miałoby być definitywnym potwierdzeniem tezy, że życie, a w szczególności życie ludzkie, nie jest czymś wyjątkowym we wszechświecie, a zatem do jego powstania nie potrzeba jakiegoś wyjątkowego, nadprzyrodzonego czynnika, lecz jest wynikiem splotu określonych warunków, które są dostępne we wszechświecie. Życie ludzkie (także to duchowe) byłoby więc wynikiem tylko i wyłącznie ewolucji materii. To jednak, że istniałyby istoty duchowe poza Ziemią, nie pozwala jeszcze przyjąć twierdzenia, że życie duchowe powstało z materii. Dusza duchowa, odpowiadająca i kierująca duchowymi funkcjami żyjącej istoty, jako niematerialna nie może być przedmiotem ewolucji, nie może w żaden sposób wyewoluować z materii. „W przypadku człowieka - stwierdza Jan Paweł II - mamy do czynienia z różnicą natury ontologicznej, można wręcz powiedzieć ze «skokiem» ontologicznym" ${ }^{22}$. Dlatego też moment przejścia do sfery

${ }^{21}$ Sobór Watykański II, Konstytucja o Kościele w świecie współczesnym Gaudium et spes, 22.

22 Jan Paweł II, Magisterium Kościoła wobec ewolucji. Przemówienie do członków Papieskiej Akademii Nauk, „L'Osservatore Romano” 1 (1997), s. 19. 
duchowej nie może być przedmiotem obserwacji dla nauk przyrodniczych. Może być ona dostępna tylko dla refleksji filozofii, a także teologii, która odkrywa ostateczny sens ludzkiego ducha. Życie duchowe, istniejące hipotetycznie w kosmosie, wymagałoby interwencji stwórczego Ducha, analogicznej do tej, jaka miała miejsce na Ziemi.

Po trzecie, można postawić pytanie, czy poszukiwanie innych istot żywych, a w domyśle doskonalszych od nas samych, nie jest współczesnym echem odwiecznej tęsknoty człowieka ku doskonałości, ku osiągnięciu wyższej formy rozwoju i istnienia, które przekracza obecnie dostępne i przewidywalne w przyszłości stany ewolucji ludzkości? Nie chodzi tu tylko o jakościowo lepsze i stojące na wyższym poziomie technicznym życie człowieka, bo to może mu przynieść rozwój i postęp, który już teraz stał się „nową religią". Jest to tęsknota za osiągnięciem takiego stanu, który przekracza samą miarę człowieczeństwa - będzie prawdziwie „nowym człowiekiem", żyjącym na nowej Ziemi. W tej koncepcji pragnienie królestwa Bożego jest zastąpione pragnieniem królestwa obcych, w którym z pewnością (choć ta „pewność” zdaje się być bardziej nadzieją niż wiedzą) nie ma śmierci, pokonane są wszystkie choroby i rozwiązane wszystkie problemy, które obecnie dotykają ludzkość, takie jak wojna, przemoc, niesprawiedliwość społeczna. W dążeniu do odkrycia innych cywilizacji człowiek poszukuje perspektywy, która byłaby transcendentna wobec niego (czy nie jest to zlaicyzowana forma naturalnej potrzeby Boga, jaką człowiek w sobie nosi?). Tylko taka bowiem perspektywa może dać człowiekowi prawdziwą nadzieję. Benedykt XVI krytykując nadzieję zbudowaną na idei doczesnego postępu, napisał:

Człowiek potrzebuje innej nadziei, która idzie dalej. Staje się jasne, że może zaspokoić go jedynie coś nieskończonego, co zawsze będzie czymś więcej niż to, co kiedykolwiek może osiągnąć ${ }^{23}$.

Czy to poszukiwanie ,istot pozaziemskich”, rozumianych nie tyle jako mieszkających w innej przestrzeni kosmicznej, ile mieszkających inaczej, stanowiących odrębną jakość istnienia nie mogłoby być dla teologii punktem wyjścia dla nowej ewangelizacji analogicznie jak nawiązanie

${ }^{23}$ Benedykt XVI, Encyklika Spe salvi (30.11.2007), 30, Kraków 2007. 
św. Pawła do ołtarzy innych bogów, które ateńczycy postawili na swoim areopagu?

Na koniec jeszcze jedna uwaga. Brak odkrycia w najbliższej okolicy Ziemi planety zdolnej do życia (a to jest już faktem bezspornym), dowartościowuje Ziemię jako miejsce, które stanowi dom dla ludzkości. A zatem, tym więcej wysiłku trzeba włożyć, aby zachować ją jako zdolną do życia dla następnych pokoleń. Można by to określić jako kosmiczne uwarunkowanie dla ekologii, lecz również dla pokojowego współżycia narodów. Człowiek nie może się bezpośrednio przenieść w inny obszar kosmosu i tam zamieszkać. Jeśli chce to uczynić, musi stworzyć sobie do tego warunki, adaptując przyszłe miejsce do życia. Wymaga to nie tylko wiedzy i możliwości technicznych, ale też takich relacji społecznych, które umożliwią realizację tego zadania. To jednak, co trzeba będzie zrobić dla zagospodarowania przyszłych miejsc życia w kosmosie, jest potrzebne także na Ziemi, aby człowiek mógł na niej przetrwać.

Współcześnie jednak wydaje się, że ciężar działań dotyczących kwestii życia w kosmosie koncentruje się bardziej na możliwości stworzenia habitatu na innych planetach naszego Układu Słonecznego, przede wszystkim na Marsie. Te działania wydają się bardziej prawdopodobne w dającej się przewidzieć przyszłości. Zanim to jednak nastąpi, bieżącym i pilnym zadaniem jest troska o tę przestrzeń życiową, która już została ludzkości dana i zarazem zadana poleceniem Stwórcy: „Bądźcie płodni i rozmnażajcie się, abyście zaludnili ziemię i uczynili ją sobie poddaną" $(\mathrm{Rdz} 1,28)$. Być może należałoby odczytać ten nakaz w szerszym znaczeniu: „abyście zaludnili kosmos i uczynili go sobie poddanym”. Wcześniej jednak ludzkość musi zatroszczyć się o własne przetrwanie.

Prawdziwie chrześcijańską perspektywę w spojrzeniu na wartość i piękno wszechświata, jak też wyzwania teraźniejszości, które stoją przed człowiekiem, syntetycznie wyraził papież Franciszek w końcowym fragmencie swojej encykliki Laudato si':

U kresu naszego życia spotkamy się twarzą w twarz z nieskończonym pięknem Boga (por. 1 Kor 13,12) i będziemy mogli z radosnym podziwem odczytywać tajemnicę wszechświata, który wraz z nami będzie uczestniczył w pełni bez końca. [...] Oczekując, zjednoczymy się, aby zająć się tym domem, który został nam powierzony, wiedząc, że wszystko, co jest w nim dobre, zostanie zebrane na niebiańskiej 
uczcie. Wraz ze wszystkimi stworzeniami pielgrzymujemy na tej ziemi, szukając Boga, ponieważ ,jeśli świat ma początek i został stworzony, to poszukuje tego, kto go stworzył, tego, który dał mu początek, tego, który jest jego Stwórcą"24.

$$
*^{*} *
$$

Benedykt XVI w trzeciej części swojej trylogii na temat Jezusa z Nazaretu pt. Dzieciństwo, komentując historię mędrców ze Wschodu, ich badanie zjawisk niebieskich, które w konsekwencji doprowadza ich do Betlejem, stwierdza dwa fakty, które rzucają nowe światło na temat życia w kosmosie. Po pierwsze, stwierdza prawdę, która zawsze była obecna w refleksji teologicznej, że kosmos mówi o Chrystusie, ale też, że „dla człowieka w jego realnej kondycji jego język nie jest w pełni zrozumiały" ${ }^{25}$. Dlatego też mędrcy korzystali z interpretacji świętych ksiąg i proroctw w nich zawartych. Tylko wtedy mogli właściwie odczytać przesłanie kosmosu. Kosmos sam w sobie nie jest w stanie odpowiedzieć na wszystkie pytania człowieka i nie jest w stanie rozwiązać wszystkie problemy, z jakimi boryka się człowiek, dlatego że problemy te nie są wynikiem tylko zewnętrznych, „kosmicznych” okoliczności, ale sięgają wnętrza człowieka, jego natury. Po wtóre, biblijna opowieść o gwieździe prowadzącej mędrców wskazuje na pewien „,przewrót antropologiczny”, który polega na tym, że człowiek w oczach Boga, który sam stał się człowiekiem ,,jest większy niż wszystkie moce świata materialnego i ma większą wartość niż cały wszechświat"26.

Poszukiwanie życia pozaziemskiego, niezależnie od naukowego uzasadnienia podjęcia takich działań, które nie należą do kompetencji teologii, ujawnia prawdę o człowieku nie tylko jako istocie posiadającej wrodzoną potrzebę poznawania świata i poszukiwania odpowiedzi na nurtujące go pytania i problemy, ale jako tego, który jest zdolny przekraczać granice kosmosu i sięgać myślą i pragnieniem w sferę rzeczywistości ponadmaterialnych, w stronę transcendencji, której wypełnieniem jest Bóg, stwórca kosmosu i człowieka.

24 Franciszek, Encyklika Laudato si' (24.05.2015), 243-244, Kraków 2015.

25 Benedykt XVI, Jezus z Nazaretu. Dzieciństwo, tłum. W. Szymona, Kraków 2012, s. 134.

26 Benedykt XVI, Jezus z Nazaretu. Dzieciństwo, dz. cyt., s. 136. 


\section{Bibliografia}

Abramowicz M., Pan Bóg jest wyrafinowany, ale nie perfidny, „Przewodnik Katolicki” 18 (2016), s. 24-27.

Benedykt XVI, Encyklika Spe salvi (30.11.2007), Kraków 2007.

Benedykt XVI, Jezus z Nazaretu. Dzieciństwo, tłum. W. Szymona, Kraków 2012.

Domingo de Soto, De dominio, Salamanca 1560.

Domingo de Soto, Relección De Dominio, ed. de Jaime Bufrau Prats, Granada 1964.

Franciszek, Encyklika Laudato si' (24.05.2015), Kraków 2015.

Francisco de Vitoria, O Indianach, Warszawa 1954.

Hałaczek B., Ewolucja poglądów teologicznych na ewolucję, „Śląskie Studia Historyczno-Teologiczne" 31 (1998), s. 17-25.

Hawking S., Krótka historia czasu, Warszawa $2015^{2}$.

Heller M., Czy kosmita może być zbawiony, „Tygodnik Powszechny” (8.06.2008), s. 28-29.

Jan Paweł II, Magisterium Kościoła wobec ewolucji. Przemówienie do członków Papieskiej Akademii Nauk, „L'Osservatore Romano” 1 (1997), s. 18-19

Jan Paweł II, Encyklika Redemptor hominis (4.03.1979), Kraków 1982.

Katechizm Kościoła katolickiego (11.10.1992), Poznań 1984.

Łukaszuk T.D., Zwiazzek dogmatu o grzechu pierworodnym z monogenizmem w katolickiej teologii ostatniej doby, Warszawa 1976.

Rahner K., Grzech pierworodny a ewolucja, „Concilium” 1-10 (1966-1967), s. 288-295.

Sobór Watykański II, Deklaracja o stosunku Kościoła do religii niechrześcijańskich Nostra aetate (28.10.1965), w: Sobór Watykański II, Konstytucje, dekrety, deklaracje, tekst polski, nowe tłum., red. M. Przybył, Poznań 2002 (dalej: SWD), s. 333-337.

Sobór Watykański II, Konstytucja dogmatyczna o Kościele Lumen gentium (21.11.1964), w: SWD, s. 104-166.

Sobór Watykański II, Konstytucja o Kościele w świecie współczesnym Gaudium et spes (7.12.1965), w: SWD, s. 526-606.

Stwora T., Próby interpretacji nauki o grzechu pierworodnym $w$ świetle teorii ewolucji w teologii katolickiej, „Studia Ełckie” 14 (2012), s. 453-468. 